\title{
Erik Arup og Island \\ eller \\ Da Christian X fandt et nyt kongerige
}

af cand. mag. Thyge Svenstrup

Island fejrede 17. juni 1994 50-årsdagen for den definitive adskillelse fra rigsfællesskabet med Danmark. Ved folkeafstemningen i Island foråret 1944 stemte 95 pct. af vælgerne for den republikanske forfatnings indførelse og 97 pct. for bortfald af den Dansk-Islandske Forbundslov af 1. december 1918; stemmeprocenten var næsten 100 .

I historikeren Erik Arups nyåbnede arkiv er påtruffet det her for første gang publicerede manuskript, der kan betragtes som anekdotiske randnoter til Forbundslovens tilblivelse.Vi møder her ikke den udæskende og stridbare, men den muntre og vittige Erik Arup (1876-1951), hvem patos i omtalen af "de store dage" i danmarkshistorien dog heller ikke er fremmed, hvad der mærkes i slutningen af den lille opsats.

Erik Arups ry er særlig knyttet til hans Danmarks Historie, hvis udgivelse i 1925 og 1932 (3. bind posthumt 1955) begge gange rejste en pressestorm af sjælden styrke. En enkelt avis (Nationaltidende) brugte ligefrem på én måned ikke mindre end otte (!) store kronikker til imødegåelse af de kætterske synspunkter. Arups konservative modstandere skreg op om anti-militaristiske, anti-monarkistiske og antiklerikale tendenser i Danmarkshistorien, i øvrigt ikke uforståeligt.

Mindre kendt end Arups historiske produktion er formentlig hans administrative hverv og karriere. 21. december 1907 forsvarede han sin disputats og drog derefter på et års studierejse til London, Lübeck og Hamburg, men blev herfra kaldt hjem for 1. oktober 1908 at tiltræde en stilling som arkivar i Udenrigsministeriet; året efter forfremmedes han til overarkivar. Fra denne stilling udnævntes han 1914, 38 år gammel, under C. Th. Zahles 2. radikale regering (1913-20), til 
departementschef og statsrådssekretær, landets højeste embede, vist efter Zahles og finansminister Edvard Brandes' ønske. Arup havde allerede 1903-04 meldt sig ind i Den Radikale Klub i København, forløberen for stiftelsen af Det Radikale Venstre 1905, og forblev alle dage en varm tilhænger af partiets ideer. I mellemtiden havde han 1912 søgt historieprofessoratet ved Københavns Universitet efter J.A. Fridericia, men blev til sin store skuffelse forbigået til fordel for Aage Friis (1870-1949), hans ungdomsven, men fra da af hans livslange modstander. En dag i 1915 ringede Kr. Erslev imidlertid Arup op og sagde, at nu ville han være rigsarkivar, og at Arup så kunne blive hans efterfølger som professor, hvad han også udnævntes til året efter (1916).

Arup har på manuskriptet noteret: "skrevet $5 / 5$ og 8/5 1937, opgivet at trykke 10/5 37." Grunden hertil kendes ikke med sikkerhed. Formentlig har det med modtagelsen af hans Danmarkshistorie at gøre. Den voldsomme kritik i den konservative del af dagspressen også ved udgivelsen af 2. bind af værket nedsatte i alvorlig grad Arups lyst til at publicere. I 1930'erne offentliggjorde han så at sige intet. Hertil kom den forbitrede strid, Arup blev indviklet i 1936 ved besættelsen af det ledige professorat efter Aage Friis. En strid, der reelt først endte tre år senere i civilretten i Helsingør i den såkaldte Vilh. la Cour-sag. Alt med pressens store bevågenhed.

Det her trykte lille arbejde har især interesse ved de muntre erindringsglimt, Arup giver af de tre politikere i den danske forhandlingsdelegation, der 1918 sendtes til Island: J.C. Christensen (1856-30), konseilspræsident 1905-08, den centrale personlighed i dansk politik i de to første årtier af dette århundrede. F. J. Borgbjerg (1866-1936), kendt socialdemokratisk agitator, redaktør og politiker. Og Christopher Hage (1848-1930), delegationens formand, finans- og trafikminister i det første venstreministerium 1901-05. Ved 1. verdenskrigs udbrud 1914 udnævnt af Zahle til formand for den såkaldte overordentlige kommission, 1916 til vikar for Edv. Brandes under dennes sygdom og derefter til handelsminister. Karakteristisk for Arups portrætter er den sympati, han fremstiller de store, folkelige førere med: socialdemokraten Borgbjerg og venstreføreren J.C. Christensen. Har nogen anden venstremand fået et så pænt eftermæle af en radikal som J.C. Christensen? Arups radikale partifælle, den lidt aristokratiske Hage, står derimod svagere i billedet.

Det dansk-islanske forhandlingsudvalg udnævntes ved kgl. resolution 15. juni 1918 og ankom til Reykjavik 29. juni. Forhandlingerne afsluttedes 18. juli 1918. 


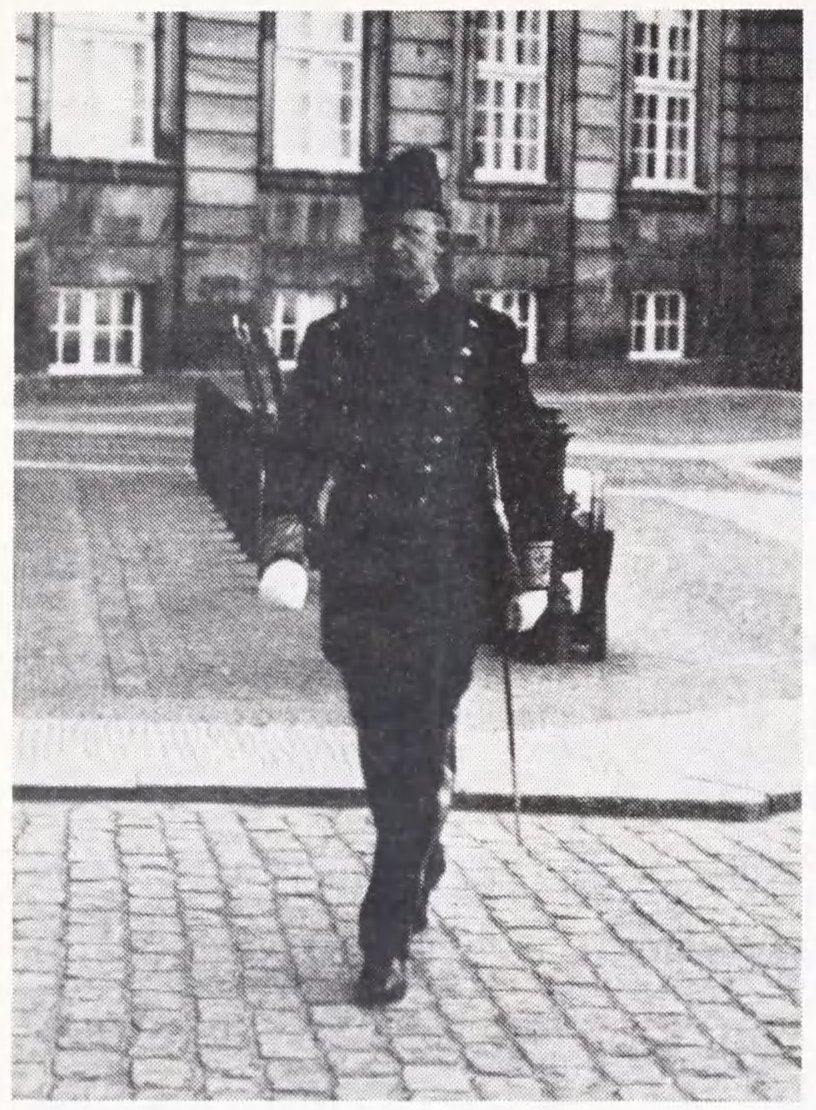

Erik Arup i fuld statsrådssekretæruniform på

Amalienbog Slotsplads engang mellem 1914-16.

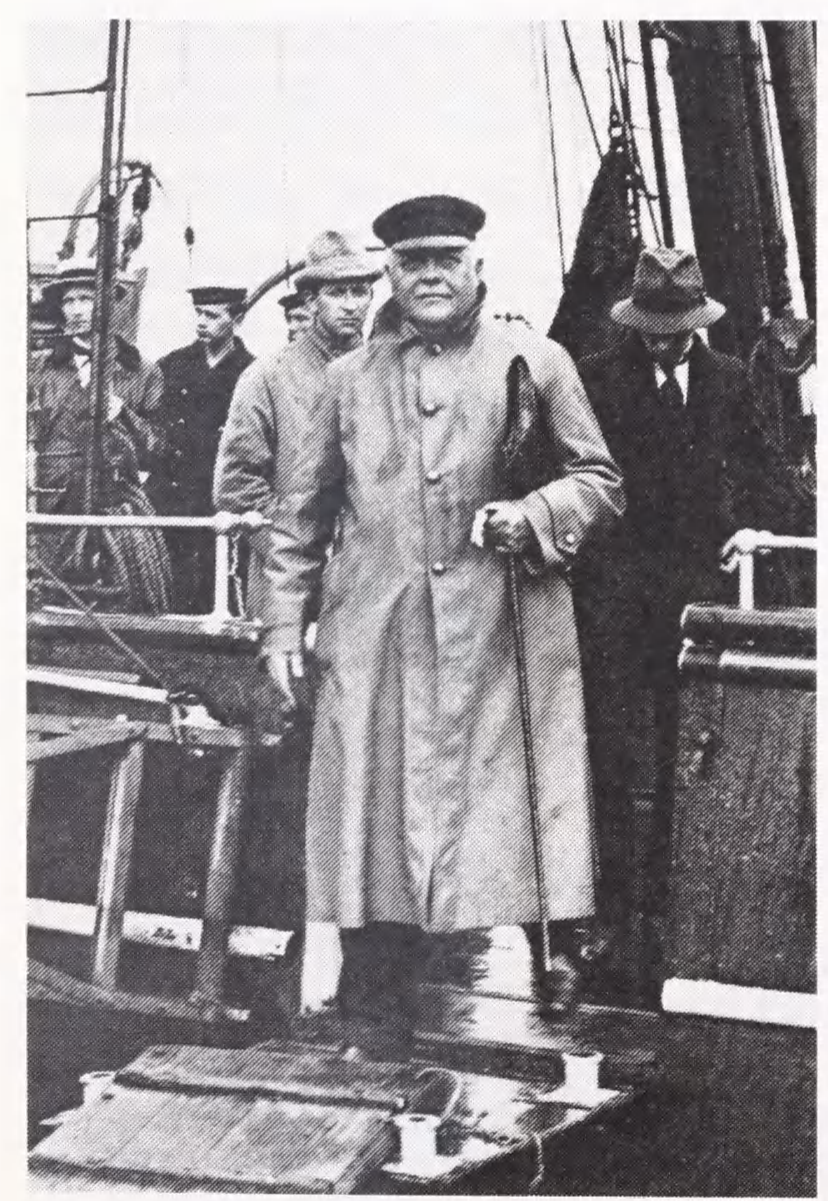

J.C. Christensen 1918.

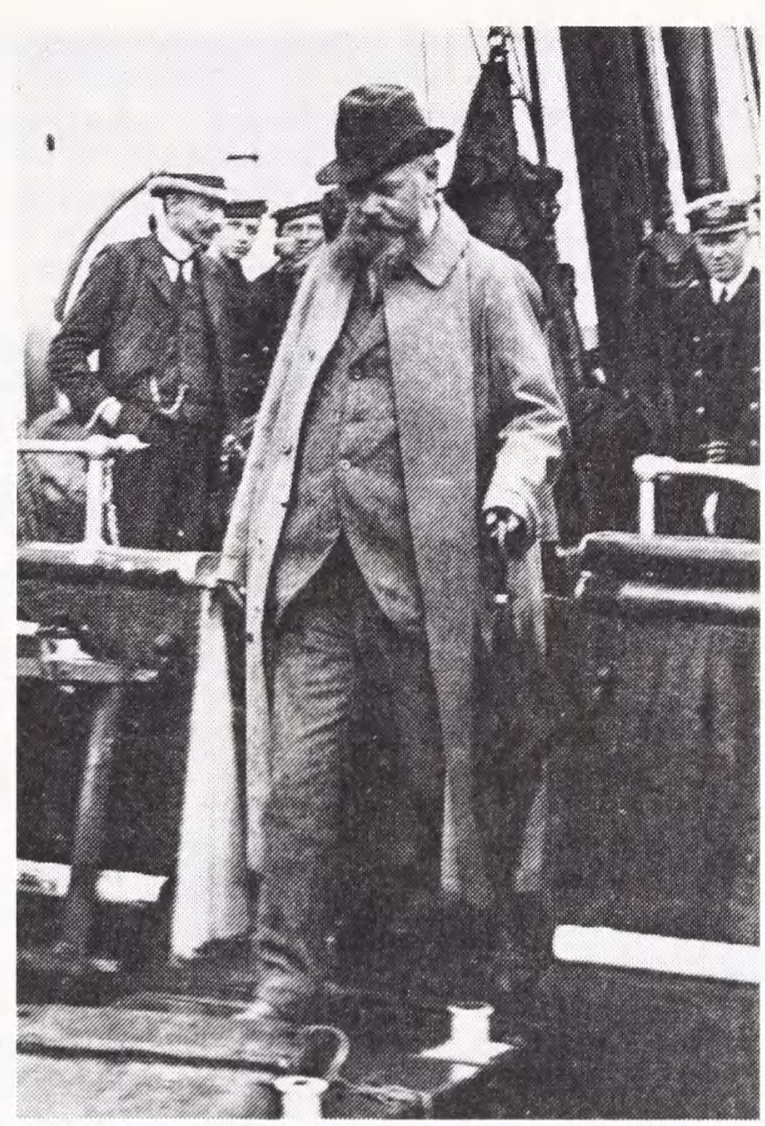

FJ. Borgbjerg 1918.

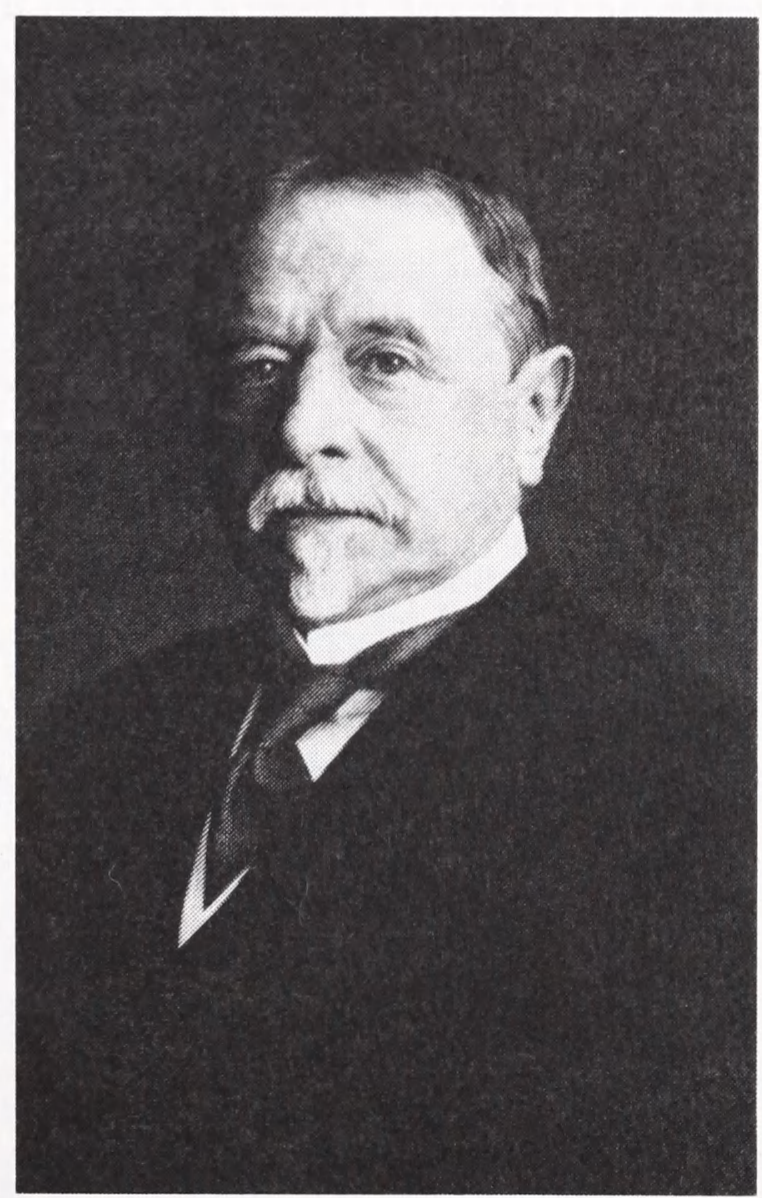

Christopher Hage som ældre. 
Det afgørende ord i den danske delegation havde J.C. Christensen på grund af sin stilling i det store venstreparti. Arup spillede imidlertid en central rolle. En overgang så det ud til, at forhandlingerne ville bryde sammen, medlemmerne af det danske udvalg regnede med at måtte rejse hjem. Efter islandsk ønske nedsattes imidlertid da et underudvalg bestående fra dansk side af Arup og Hage, fra islandsk af Bjarni Jónsson frá Vogi ${ }^{1}$ (Selvstændighedspartiet) og Einar Arnórsson² (valgt af Hjemmestyrepartiet og Selvstændighedspartiets mindretalsfraktion). Efter en række vanskelige drøftelser kunne Arup og Hage tilsidst udarbejde et nyt forslag, der kom til at danne grundlag for de endelige forhandlinger om Forbundsloven.

Arup må således betragtes som en meget centralt placeret kilde til forhandlingerne i Reykjavik sommeren 1918. Senere blev han 1919-50 medlem af og (fra 1921) sekretær i det nyoprettede Dansk-Islandske Navn, 1920-46 medlem af DanskIslandsk Forbundsfond og fra 1936 til sin død medlem af Den Arnamagnaanske Kommission. Af alle disse grunde var han også udset til at skrive afsnittet om Danmark og Island i værket Den Danske Rigsdag 1849-1949. I efteråret 1949 fremsatte han imidlertid ønske om, at arbejdet måtte blive overdraget en anden. Efter samråd med Arup blev det Jørgen Steining. Denne har bl.a. bygget sin skildring på utrykt materiale stillet til rådighed af Arup, herunder den danske delegations fortrolige beretning om forhandlingerne i Reykjavik 1918, ligesom det af Arups arkiv ses, at Steining har konsulteret ham under arbejdet.

Forholdet mellem Island og Danmark blev i de tre sidste årtier af det 19. århundrede stadig dårligere, mens landet lededes af Højreregeringer. Landsstillingsloven af 2. januar 1871 og forfatningsloven for Islands særlige anliggender af 5. januar 1874 styrkede den islandske separatisme. I tidsrummet 1875-1901 indstillede danske ministre i statsrådet til kongen i ikke mindre end omkring 40 tilfælde at nægte stadfæstelse af islandske særlove, der i forvejen var vedtaget af Altinget. Den hovedansvarlige for denne udvikling var justitsminister (1875-96) og minister for Island J. Nellemann, berygtet for sit sofistiske forsvar for Estrups provisorielovgvning.

Efter Systemskiftet 1901 var der i Danmark politisk vilje til at få Islands forfatningsmæssige stilling ordnet på en måde, der imødekom islændingene. En danskislandsk kommission nåede i 1908 frem til en løsning, der syntes at tilfredsstille alle. Kommissionsforslaget faldt imidlertid, fordi ét ud af de syv islandske medlemmer nægtede at underskrive. Som et forarbejde til kommissionens arbejde skrev 
Erik Arup en Kortfattet Oversigt over Danmarks Forhold til Island med Hensyn til Handelens Organisation, offentliggjort som en del af kommissionens betænkning $1908 .{ }^{3}$ Såvidt det ses, var det første gang, Arup blev inddraget i det islandske spørgsmål. Han arbejdede på dette tidspunkt på sin disputats, der handlede om handelsformer i Nordvesteuropa 1350-1850, og er vel derfor blevet anset for velkvalificeret til arbejdet.

De fornyede forhandlinger i Reykjavik 1918 skyldtes dels stadige islandske klager og utilfredshed i de mellemliggende år, dels dansk ængstelse for, at Island ville benytte situationen under 1 . verdenskrig til at gennemtvinge sin fuldstændige løsrivelse fra Danmark ved Englands og USAs hjælp.

Første paragraf i Forbundsloven af 1. december 1918 fastslog, at Danmark og Island var "frie og suveræne Stater forbundne ved fælles Konge" og den i Forbundsloven "indeholdte Overenskomst". Bl.a. skulle de to landes statsborgere nyde lige rettigheder med det andet lands statsborgere og Danmark på Islands vegne varetage dette lands udenrigsanliggender. Ifølge Forbundsloven havde landene ret til efter 25 år énsidigt at opsige loven. Den endelige unionsopløsning 1943-44 skete ved, at Island benyttede sig af denne ret. Det vakte i visse kredse i Danmark irritation, fordi landet på grund af den tyske besættelse og regeringens tilbagetræden 29. august 1943 var forhindret $\mathrm{i}$ at forhandle. Den danske afdeling af nævnet offentliggjorde 1944 ved Erik Arup Dansk-Islandsk Nævns Protokol over Forhandlingerne i Aarene 1919-1939 for at give den islandske og nordiske offentlighed kendskab til Danmarks holdning over for Island i tiden under Forbundsloven.

Det Dansk-Islandske Nævn bestod indtil 1926 af seks, derefter af otte medlemmer, med halvdelen valgt af hver af de to lande. Dets opgave var at gennemgå alle regeringsforslag for at påse, at ingen bestemmelser deri stred mod Forbundsloven eller var til skade for det ene lands statsborgere i det andet land. Den danske afdeling af nævnet fik også praktisk indflydelse på lovgivningen vedrørende de to lande. Det samlede nævn mødtes skiftevis i Reykjavik og København hvert andet år. Arup indtog helt fra begyndelsen en førende stilling i nævnet og var den eneste, som var medlem fra nævnets oprettelse til Forbundslovens ophævelse 1950. Spørgsmålet om udlevering af islandske håndskrifter og museumsgenstande i danske samlinger havde Arups særlige interesse. Island krævede alt tilbageleveret, som engang havde været $\mathrm{i}$ landet. Arup indtog en meget imødekommende holdning til disse spørgs- 
mål, men præciserede, at Island intet juridisk krav havde herpå. Det var også på Arups forslag 1933, at islændingene fik ligelig repræsentation i Den Arnamagnæanske Kommission (1936).

Efter befrielsen deltog Arup 1945-46 i forhandlingerne i København og Reykjavik om en række spørgsmål opstået ved Altingets opsigelse 25. februar 1944 af Forbundsloven. På grund af specielle problemer mellem Færøerne og Island stadfæstede kong Frederik IX fra dansk side dog først så sent som 16. maj 1950 loven om Forbundslovens ophævelse. Ved denne lejlighed fremhævede og takkede statsminister Hans Hedtoft i Rigsdagen Erik Arup for, hvad han ved sit arbejde og sin interesse og sin indsigt havde betydet for hele forholdet mellem Danmark og Island.

Det er i denne større sammenhæng, Arups her publicerede lille opsats må ses, som et led i over 40 års interesse og arbejde for forbedringen af de dansk-islandske forbindelser.

\section{Erik Arup:}

\section{Da kong Christian fandt et nyt kongerige}

Jeg blev ringet op af Munch ${ }^{4}$ engang i foraaret 1918, om jeg vilde være det radikale partis repræsentant i en delegation, der skulde sendes til Reykjavik for at forhandle med Islændingene om en nyordning af forholdet mellem de to lande.

Jeg blev henrykt over det ærefulde hverv. Jeg havde i sin tid, vel 1906, skrevet om oprindelsen til den islandske monopolhandel til kommissionen 1907, jeg havde senere som departementschef og statsraadssekretær 1914-1916 været vidne til og deltaget i de pinagtige og smaalige forhandlinger om det islandske flag. ${ }^{5}$ Jeg havde under disse forhandlinger lært Einar Arnórsson, Sveinn Björnsson ${ }^{6}$ og Gudmundur Hannesson $^{7}$ at kende, højt begavede og glimrende personligheder, hvis venskab jeg haaber at have bevaret til dagen i dag. Jeg var oprigtigt opfyldt af beundring for det islandske folks kamp for at opnaa anerkendelse som en ny nation, et nyt politisk samfund i Norden, og jeg var fast bestemt paa, at jeg, som jeg vidste i bedste overensstemmelse med mit parti, vilde gøre mit til, at det islandske folk naaede sit maal.

Hvad jeg nu her ønsker at berette om, er ikke forhandlingernes indhold i Reykjavik 1918, men blot anekdoter om den danske delegations tilværelse paa rejsen 
til og i Island, som maaske kan more.

Delegationen bestod af handelsminister Christoffer Hage, der var omved 70, men dog havde paataget sig det besværlige hverv at være delegationens formand, af I.C. Christensen, der var omved 60, som Venstres repræsentant, hvis gamle kærlighed til det islandske folk her ikke fornægtede sig, af Borgbjerg, der var 50 og socialdemokrat og altsaa af mig, der var 40 og det radikale partis repræsentant. Højre havde ikke villet deltage.

I øsende regnvejr og storm rejste vi fra København, i øsende regnvejr og storm kom vi til Bergen. Der mødte daværende kaptejn Lorch op, der skulde tage os til Reykjavik i 'Islands Falk'8; det var krigstid og kun inspektionsskibet turde færdes på havet. Kaptejnen meldte, at der var storm og tilraadede, at delegationen ventede, til den var løjet af. Da paatog I.C. Christensen sig helteposituren og sagde: er kaptejnen ængstelig for at gaa ud? Nu var Lorch en glimrende sømand, og denne fornærmelse var ham for meget: vi sejler altsaa i morgen kl. 9.

I.C. Christensen kom til at fortryde sine høje ord. Vi sejlede kl. 9 og var taabelige nok til at staa og betragte den norske skærgaard, til vi kl. 11 passerede Holmen graa og kom ud i Atlanten. For et hav der var; Islands Falk vuggede som en nødeskal derpaa. Kl. 11 var frokosten. Borgbjerg var allerede gaet til køjs. Hage drak først en kop the og forlod os. Tilbage var I.C. Chrisensen, jeg og vor islandske sekretær Magnus Jonsson ${ }^{9}$ I.C. Christensen foreslog sild og snaps, som vi fik, men så kom skibslabescowes, som jeg ikke rigtigt syntes om, og tilsidst var der et stykke stegt fiskefilet, som blev saa stort i min mund, at jeg ikke kunne svælge det, men maatte op og gaa til rælingen. Noget efter kom I.C. Christensen op med en slukket cigar i haanden. Jeg spurgte ham, hvorledes det var gaaet, efter at jeg havde forladt selskabet. Jo det var gaaet meget godt, Magnus Jonsson og han havde faaet et stykke stegt aal og en snaps til; men saa, sagde I. C. Chrisensen, kom der et fad med stegte kyllinger, og da jeg saa Magnus Jonsson stikke sin gaffel i en halv kylling og tage den over paa sin tallerken, gik jeg min vej, for det fraadseri ville jeg ikke være vidne til.

I brandstorm sejlede vi fra Bergen til Thorshavn. Det var rart at faa fast grund under fødderne. I.C. Christensen og jeg gik ned i messen og spillede l'hombre med de unge officerer. Kl. 3 om natten gik vi op paa dækket og saa det herlige syn af Færøerne liggende paa havet i den opgaaende sols straaler.

Vi kom til Reykjavik. Vi var den islandske regerings gæster og boede derfor i det 
dengang fornemste hus i hele Reykjavik, der nu er det danske gesandtskabs hus, et cementhus, der var bygget af den daværende islandske førsteminister Jon Magnussons ${ }^{10}$ to svogre, og som de havde stillet til raadighed for os. Hage som delegationens formand boede dog i førsteminister Jon Magnussons egen villa tæt ved. Men han kom naturligvis næsten hver aften over for at tale med os. Island var dengang forbudsland, saa naar Hage kom om aftenen, var der altid citronsodavand paa is i køkkenet, som blev tilbudt ham med vendingen: ønsker excellencen champagnen serveret? Hage saa surt, men han havde medført en kasse havanacigarer, af hvilken han selv kun røg een efter middag, men naar han syntes, at vi andre ogsaa havde opført os helt pænt under dagens forhandlinger, kunde det ske, at han tilbød ogsaa os een af havanakassen. Vi blev glimrende beværtet. Helleflyndere, laks og foreller var hver dag paa vort bord. Men kogt torsk fik vi ikke, skønt vi gerne vilde have det, det var efter vore værters mening en alt for simpel fisk for den fornemme delegation.

Det islandske socialdemokrati var netop da blevet startet af Olafur Fridriksson ${ }^{11} \mathrm{og}$ Jon Baldvinsson ${ }^{12}$. De var naturligvis glade over, at en saadan socialdemokratisk dansk heros som Borgbjerg var kommet til Island. Han skulle tale i alle deres foreninger. Det ærgrede Hage noget, at et medlem af delegationen fik en saa pludselig succes, delegationens medlemmer burde efter hans mening ikke saaledes hver for sig i Island propagere deres politiske ideer. Men saa en aften kom Borgbjerg hjem fra et islandsk socialdemokratisk møde, hvor han havde talt. Han havde med en frisk rose, som han havde faaet af en kvindelig meningsfælle. En frisk rose var dengang i Island en saadan sjældenhed, at den var en særlig æresbevisning fra en beskeden tilhører til den store taler. Der blev skrevet dumme ting i danske blade om denne ene rose. Men alle vi, der blot engang har hørt Borgbjerg tale, $i$ alt fald $i$ hans senere aar, vidste og ved, at denne enkelte islandske rose var hans med rette. Han har ved sin friskfødte veltalenhed henrevet sine islandske tilhørere, som han utallige gange henrev os, sine danske tilhørere.

Borgbjerg havde sin store indflydelse i forhandlingerne derved, at det var ham, der foreslog og fik vedtaget bestemmelsen om den lige statsborgerret i forbundsloven. Fælleskabet mellem Danmark og Island kunde efter hans opfattelse ikke bestaa alene i et kongefælleskab, han mente, at den ogsaa maatte finde sit udtryk i et statsborgerfællesskab. En islænding i Danmark maatte have alle danske statsborgerrettigheder, en dansker i Island alle islandske statsborgerrettigheder, hvis der 
vedblivende skulde være tale om et fællesskab mellem de to folk. Denne lige statsborgerret var en helt ny juridisk figur, som derfor voldte de gamle fagskolede jurister meget hovedbrud. Men Borgbjerg gjorde sig ikke op i det enkelte, om en saadan aftale vilde være mere til gavn for det ene eller det andet folks statsborgere; han troede, at den vilde være til gavn for begge. Først eftertidens erfaring har vist, at ligeretten var saa langt til største fordel for islændingene.

Det var mit indtryk, at I.C. Christensen var henrykt for disse forhandlingsdage i Reykjavik. Det var vistnok første gang, han siden 1905 igen kom paa fortrolig talefod med Hage ${ }^{13}$, og hans omsorgsfulde veneration for Hage var rørende. Men da jeg efter fælles beslutning havde tilbragt en søndag, hvor de andre var ved Ælfusaa, med at skrive motiver til forbundsloven, sagde I.C. Christensen, da han kom tilbage om aftenen: Det kunde De have sparet Dem, for Hage skriver det altsammen om igen imorgen. Jeg skylder vel mig selv at tilføje, at det holdt ikke helt stik.

Mærkeligere var, at I.C. Christensen en aften, som han, Magnus Jonsson og jeg sad og spillede l'hombre, blev højst bekymret over, at Borgbjerg ikke kom tilbage fra en udflugt paa Esja, som han havde givet sig ud paa sammen med Olafur Fridriksson. Borgbjerg vilde nemlig bestige Esja ${ }^{14}$ fra Reykjaviksiden, og det lykkedes ham mærkeligt nok, men først ud paa natten. Næste morgen var ingen lykkeligere end I.C. Christensen over, at Borgbjerg var sluppet helskindet hjem.

Jeg selv glemmer ikke, at efter den første nats søvn i Reykjavik blev jeg vækket søndag morgen ved, at I.C. Christensen bankede paa min dør: kom nu professor og se paa Snefjællsjøklen, maaske faar De aldrig denne snedronning at se saa skøn og hvid som idag.

Og saa gik vi paa I.C. Christensens forslag alle til gudstjeneste i Reykjaviks domkirke og da, om ikke før forstod vi, hvor skønt og klangfuldt det islandske sprog er, men ogsaa saa helt anderledes end de andre nordiske sprog - her taltes ud af nordisk oldtid, et nordisk sprog, som var blevet praktisk talt helt uforstaaelig for os, men som vi vidste var paa en forundelig maade en del af vor egen fortid. En frasprængt rent nordisk stamme, som med en meget umild natur og i stor fattigdom havde bevaret sin stolte nationale egenhed, gav sig her tilkende. Denne gudstjeneste i Reykjavik styrkede sikkert os alle i bevidstheden om rigtigheden af vort forehavende.

Der var dette pinlige pengespørgsmaal, som Jon Siggurdsson ${ }^{15}$ havde rejst, ikke 
af pengegriskhed, men for at bringe Danmark og Island paa lige fod med hinanden, for at Danmark skulde vide, at naar Island var blevet fattigt, var det Danmarks skyld. I.C. Christensen foreslog en dag, at vi skulde gøre en ende på denne smaalige strid ved at foreslaa oprettelsen af et fond paa 2 mill. kr., der skulde støtte dansk og islandsk aandsarbejde og den aandelige forbindelse mellem de to lande. Deraf kom det dansk-islandske og det islandsk-danske forbundsfond hvert paa 1 mill. kr., der siden 1918 har været til megen nytte for begge folk. Forslaget syntes os alle saa selvfølgelig rigtigt, da det blev fremsat af I.C. Christensen, og beslutningen derom kom ogsaa i forbundsloven. Men senerehen gav jeg mig til at tænke paa, om I.C. Christensen egentlig havde nogen bemyndigelse hjemmefra til at fremsætte det; jeg gik saa vidt, at jeg en dag spurgte Edvard Brandes, der 1918 var finansminister, derom, men han kunde intet huske om en sadan bemyndigelse. Jeg tror, at tanken om dette fond var I.C. Christensens, og at han, finansudvalgets aargamle formand, har følt en vis glæde ved alene ved sin rent personlige indflydelse at kunne disponere over 2. mill. kr. af den danske statskasse. Penge som han vidste vilde komme formaal til gode, som altid havde haft hans hjertelige støtte.

Vi kom gennem forhandlingerne af 1918 18. juli, undertegnede i altingshuset $\mathrm{i}$ Reykjavik den dansk-islandske forbundslov, det nye sáttmáli ${ }^{16}$. Vi vidste alle, at den kun af formelle grunde fik betegnelsen forbundslov, fordi den som lov skulde vedtages af baade alting og rigsdag. Men i virkeligheden var den en folkeretlig aftale mellem to hver for sig selvstændige nordiske folk, der blot var blevet ført sammen af rent historiske, fortidige grunde, og kun et udtryk for, at disse to folk dog stadig nærede en vis sympati for hinanden. Siden 1814 havde de to største og rigeste nordiske stater, Norge og Sverige, været i politisk fællesskab, de var dog 1905 skiltes, uden nogen slags larm. Hvad de danske delegerede ønskede at hidføre i 1918 var alene, at afviklingen mellem de to langt mindre nordiske stater, Danmark og Island, maatte kunne komme til at foregaa paa samme maade eller maaske paa en endnu venligere maade. De 25 aar, som forbundsloven fastsatte for opløsningen af forbindelsen mellem Danmark og Island, var efter de danske delegeredes mening kun en prøvetid, hvori det skulde vise sig, om Island virkelig var i stand til at paatage sig alle de økonomiske og politiske forpligtelser, som dets konstituering som suveræn stat ville medføre.

Det er iøvrigt mærkeligt nok nu at tænke tilbage paa, at forhandlingerne i 
Reykjavik 1918 til syvende og sidst spidsede sig til i et enkelt ord, nemlig ordet suveræn. Hage, der var dansk sprogrenser, vilde have, at der i forbundslovens paragraf 1 skulde staa: Danmark og Island er selvstændige riger; Bjarni Jonsson, der var en ligesaa ivrig islandsk sprogrenser, som Hage var dansk, vilde have, at der skulde staa: Danmark og Island er suveræne riger. Hvorfor? Netop fordi ordet suveræn var internationalt og derfor lettere vilde bringe omverdenen til at forstaa, at Island virkelig fra nu af var et selvstændigt statssamfund, et suverænt kongerige. Det lykkedes den danske delegations medlemmer efter megen bearbejdelse, og da hele forhandlingen ellers var gaaet saa lykkeligt, at bevæge Hage til denne sidste efter vor mening vistnok rent sproglige, men dog nødvendige indrømmelse. Hage afgav i det sidste forhandlingsmøde en i højtidelige ord indsvøbt erklæring om, at han var villig til at ombytte ordet selvstændig med ordet suveræn ${ }^{17}$. Det var fra dansk side en aaben erklæring af det virkelige danske standpunkt; det var intet spilfægteri; vi vidste ogsaa godt, at ordet suveræn havde en helt anden klang i internationalt sprog end det tamme danske selvstændig. Det vidste ogsaa Bjarni Jonsson fra Vogi, denne mærkelige højt begavede, rabiate islandske nationalist, der netop var sat ind i den islandske forhandlingsdelegation for at vaage over, at det islandske folks selvstændighed blev sikret. Alle de andre forhandlinger var ham saa temmelig ligegyldige. Hvad det for ham gjaldt om var alene, at dette fordømte og pengegriske Danmark, der saa længe paa den efter selve Jon Siggurdsson mening mest rovgriskerige maade havde udplyndret Island og desuden rent politisk undertrykte det, nu endelig skulde gøre regnskab for sine synder og først og fremmest anerkende, at det islandske folk ikke var en dansk eller norsk afart, men en selvstændig nation med eget sprog og eget tankesæt. Ja det gik nu altsammen i opfyldelse. Da Hage med sin tynde stemme som formand for den danske delegation erklærede, at denne gerne efter Bjarni Jonssons ønske vilde ombytte det fællesnordiske ord selvstændig med det fremmede og internationale ord suveræn, fyldtes Bjarni Jonssons øjne med taarer, han forstod med eet, at nu havde han naaet sit og Islands maal, nu var det virkelig Danmarks vilje at anerkende det islandske folks egenart og den islandske stats suverænitet under kong Christian 10 som Danmarks og Islands fælles konge.

Da var det, at kong Christian, som i sin tid Saul, han som, da han var gaaet ud for at vogte sin faders aseninder, fandt et kongerige ${ }^{18}$. 
Kilder:

Arups arkiv: Ny Kongelig Samling 2874 folio.

Historikeren Erik Arups Arkiv. Registratur ved Thyge Svenstrup. Med indl. af Inga Floto. (Indsigt. Håndskriftafdelingens arkivregi-

\section{Noter}

1 Bjarni Jónsson frá Vogi (1863-1926): cand. mag. fra Kbh.s Universitet 1894; docent i latin og græsk ved Háskóli Islands (Islands Universitet) 1915-26; Medlem af Dansk-Islandsk Nævn 191826. - For islandske personalhistoriske oplysninger i artiklen takker jeg professor ved Universitetet i Bergen Magnús Stefánsson.

2 Einar Arnórsson (1880-1955): cand. jur. fra Kbh.s Universitet 1906; lærer (1908), senere professor 1911-15, 1917-32 i jura ved Háskóli Islands. Højesteretsdommer 1932-42. Altingsmedlem 1914-19, 1931-32. Justits- og kirkeminister 194244. Islands minister i Danmark 191517; medlem af Dansk-Islandsk Nævn 1918-34.

3 Betænkning afgiven af Den dansk-islandske Kommission af 1907, s. 106-13.

4 P. Munch (1870-1948) var forsvarsminister 1913-20.

5 I Statsrådet 22. nov. 1913 traf man aftale om et islandsk 'hjemmeflag', der kunne bruges i Island og på dets søterritorium. Som islandsk handelsflag skulle derimod fortsat benyttes Dannebrog.

6 Sveinn Björnsson (1881-1952): Cand. jur. fra Kbh.s Universitet 1907. Islands minister i Danmark 1920-24, 1926-40. Den isl. regerings udenrigspolitiske rådgiver 1940-41, Islands regent 1941-44; Islands pæsident fra 17. juni 1944 til sin død.

7 Gudmundur Hannesson (1866-1946): Cand. med. fra Kbh.s Universitet 1894. Lærer (1907), senere professor i medicin ved Háskóli Islands 1911-36. straturer. Nr. 1). 1992. Arups ms. heri under sign. VII. 3.

Jørgen Steining: Danmark og Island. i: Den Danske Rigsdag 1849-1949. Bd. VI. Kbh. 1953. S. 315-410.

8 Det danske skib, der varetog fiskeriinspektionen for Island.

9 Magnús Jónsson (1887-1958): cand. phil. fra Kbh.s Universitet 1908; eksamen ved præsteskolen i Reykjavik 1911; docent i teologi ved Háskóli Islands 1917, professor 1929-52. Altingsmedlem 1929-46.

10 Jón Magnússon (1859-1926): cand. jur. fra Kbh.s Universitet 1881; embedsmand på Island 1896-1917; stats- og justitsminister 1917, 1924-26; altingsmedlem 1902-19, 1923-26.

11 Olafur Fridriksson (1886-1964): initiativtager til stiftelsen af det isl. arbejderparti og isl. LO 1916; redaktør for Islands socialdemokratiske avis 1919-22.

12 Jón Baldvinsson (1882-1938): præsident i det isl. LO 1916 til sin død. Altingsmedlem 1921-38. Medlem af Dansk-Islandsk Nævn 1927 og senere.

13 Ved J.C. Christensens omdannelse 1905 af Venstreministeriet i mere højreorienteret retning forlod Hage i protest regeringen.

14 Stort fjeldmassiv nordøst for Reykjavik med stejle sider 800-900 m høje.

15 Jón Siggurdsson (1811-79), Islands førende politiker i det 19 . årh.

16 Ved gamli sáttmáli (gl. pagt) 1262 begav fristaten sig ind under den norske konges beskyttelse. Ifølge Steining har netop Arup bragt begrebet: det nye sáttmáli ind i forhandlingerne.

17 Ifølge Steining har det været Arup, der i underudvalget havde overbevist Hage om denne ændring.

18 Jfr. 1. Samuels bog kap. 9. 